\title{
USE OF GEOELECTRICAL TECHNIQUES TO DETERMINE THE IMPACT OF FACIES CHANGES ON GROUNDWATER POTENTIALS AND WATER LOGGING IN THE AREA SOUTH OF LAKE MANZALA, EAST NILE DELTA, EGYPT
}

\author{
Al Temamy, A. M. M. , M. A. Khaled and M. S. M. Barseem
}

Geophysics Department, Desert Research Center, EI Matareya Cairo, Egypt.

$\mathrm{T}$

The reclaimed desert land south of Lake Manzala area suffers from shortage of water supply and water logging during the summer months. Geoelectrical studies such as vertical electrical sounding (VES) and 2-D imaging profiles have been conducted in that area as an attempt to resolve these two problems. Interpretation of the field measurements indicated that the subsurface consists of three geoelectrical units (A, B and C) varying in depth, thickness and lithological composition. The middle unit "B" represents the water-bearing formation. It consists of three geoelectrical sub-layers (B1 and B3) of sand with clay intercalations separated by a thin clay layer B2 the resistivity of which does not exceed 0.4 Ohm.m and thickness ranges from $4-7 \mathrm{~m}$. However, the lower layer "B2" has a resistivity lower than that of the upper one due to the general increase in clay content and water salinity with depth. Also, this was confirmed by the data obtained from nearby water wells. The depth to water was found to range from $2.5 \mathrm{~m}$ in the northern part of the area to $5.9 \mathrm{~m}$ in the middle and southern parts. The thickness of the upper geoelectrical layer "B1" varies from $12.7 \mathrm{~m}$ to $26.8 \mathrm{~m}$. On the other hand, the thickness of the lower geoelectrical layer "B3" varies from 22 $\mathrm{m}$ to $32.8 \mathrm{~m}$. The lateral distribution of electrical resistivity in the study area from the cross sections of both vertical electrical sounding and $2 \mathrm{D}$ imaging results from a lateral facies change, particularly clay content, within the water-bearing formation. This clay content increases northeastward and eastward. These facies changes have a direct effect on both the quantity and quality of groundwater. This aquifer rests on a saline aquifer (C) as a result of sea water intrusion.

It is concluded that both the problems of water logging and shortage of water supply during the summer months can be simultaneously resolved by making use of the shallow aquifer (B1), especially in the western part of the study area. Moreover, 
establishing an adequate drainage system and shifting to the modern drip irrigation system instead of the traditional flood irrigation system well certainly help in reducing the effect of water logging.

Keywords: Vertical electrical sounding, 2D imaging, water logging, south of Lake Manzala, facies change, groundwater potentials.

\section{INTRODUCTION}

Great efforts have been done to increase the area of cultivated lands in Egypt, through the reclamation of desert areas. One of these areas is South of Lake Manzala. The area was found to suffer from two specific problems, the first is the shortage in surface water supply during the summer months and the second is water logging into its eastern parts. In an attempt to locate a suitable groundwater aquifer, taking into consideration the factors affecting the water quality in such a resource, a geoelectrical study was conducted. This was in the form of Vertical Electrical Soundings (VES) and TwoDimensional electrical imaging profiles. It is believed that this work would also throw light on the subsurface conditions responsible for the problem of water logging.

The study area is a part of the eastern Nile Delta province. It is located South of Lake Manzala between latitudes $30^{\circ} 45^{\prime}$ and $30^{\circ} 51^{\prime} \mathrm{N}$ and longitudes $32^{\circ} 00^{\prime}$ and $32^{\circ} 12^{\prime} \mathrm{E}$ (Fig.1) with a total area of about $100 \mathrm{~km}^{2}$.

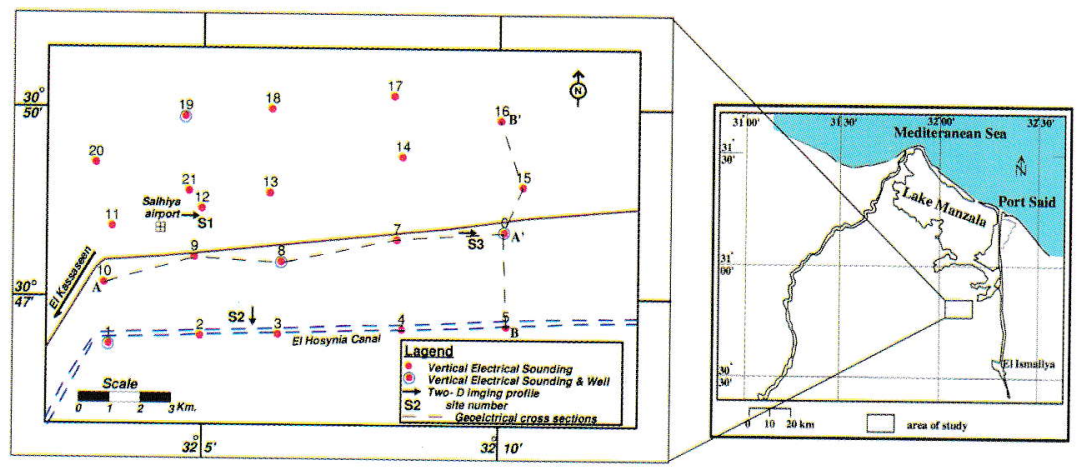

Fig. (1). Location map of sounding stations, geoelectrical cross sections and sites of Two-Dimensional imaging profiles.

\section{GEOMORPHOLOGICAL, GEOLOGICAL AND HYDROGEOLOGICAL ASPECTS}

The geomorphology and geology of the eastern part of the Nile Delta have attracted the attention of many authors such as Shukri and Ayouty (1956), Shata (1956), Said and Beheri (1961), El Fayoumy (1968), Shata 
and El Fayoumy (1970), El Shazly et al.(1975), Hefiny (1980), and Moussa (1990).

Geomorphologically, based on these studies, the eastern district of the Nile Delta comprises eight geomorphological units represented by Gebel Mokattum -Gebel Ataga structural plateau, El Ankabia-Iweibid structural plain, Belbies-El Tell El Kabier-El Salhiya old deltaic plain, Wadi El Tumaylat depression, El Manzala Lake, lacustrine and coastal plain, Nile Delta flood plain, Bittar lakes and the Isthmus basin and Desert dry drainage lines. The area of study is a part of the eastern district of the Nile Delta and is included in the Belbies-El Tell El Kabier-El Salhiya old deltaic fluviatile plains.

Geologically, the area east of the Nile Delta is occupied by Quaternary and Tertiary sedimentary rocks. They have a thickness of 400900m (Hefny, 1980). In El Salhiya plain, the Quaternary deposits consist of young aeolian deposits at the top and old deltaic deposits at the base. The first comprises fine to coarse quartz sand with remarkable variable thickness. The latter consists of fluviatile coarse quartz sand, cherty flinty pebbles and igneous fragments with a few occasional fossil wood remains. Fluviomarine deposits are represented by clays, silty clays and sand lenses. Tertiary rocks are exposed south of the study area and are represented by Pliocene, Miocene, Oligocene and Eocene rocks.

Structurally, the regional structure of the area east of the Nile Delta is a low northward dipping homocline. The dip increases the thickness of Quaternary aquifer (3m/ km northward) (Gad, 1995). Faults and folds are the most clear structural elements affecting the landscape in this area. Faults are the most common and are represented by E-W, NW-SE and NE-SW normal faults. The faulting phenomena account for the formation of morphotectonic basins such as the great Nile basin, the Helioplis, and the Sidi Dakruri basins.

The hydrogeologic setting of the area, according to Sallouma (1983), Gad (1995) and Dahab et al. (2007), shows that the main aquifer in the area is formed of Quaternary deposits (sand, sandstone, clay and shale). The clay and shale separate the aquifer into an upper unit and a lower one such that the upper unit is considered to be a free aquifer while the lower one is regarded to be of confined to semi-confined condition. Recharge is provided by the surface irrigation system. The groundwater quality ranges from fresh to brackish water type. The groundwater depth west of the study area was found to rise about $3 \mathrm{~m}$ in the period from 1975 to 2007 where the depth to water decease from $9 \mathrm{~m}$ to $6 \mathrm{~m}$. This variation is due to the use of traditional flood irrigation systems (Dahab et al. 2007). 


\section{FIELD WORK}

The field work in the study area comprises Vertical Electrical Soundings (VES) and Two-Dimensional Electrical Imaging profiles.

\section{a- Vertical Electrical Sounding}

A total of 21 Vertical Electrical Soundings (VES) were carried out in the investigated area (Fig.1). Some of these soundings were conducted near some existing wells to obtain parametric measurements to help in the quantitative interpretation of the field measurements.

The Schlumberger configuration was applied with a distance between the two current electrodes starting from 2 meters and reaching 1000 meters.

Topographic surveying was carried out with GPS to locate the position of the sounding stations as well as the approximate ground elevations.

\section{b- Two-Dimensional Electrical Imaging}

This geoelectrical technique was used along three profiles (Fig.1) using the Wenner array of electrodes. The first profile was oriented in the $\mathrm{W}$-E direction at the first site (S1) near VES 12. It has a length of $420 \mathrm{~m}$, with a unit electrode separation of $10 \mathrm{~m}$ which was increased at each traverse by one unit to reach a maximum spacing of $140 \mathrm{~m}$ (i.e. $10,20,30, \ldots . ., 140$ $\mathrm{m})$. The second profile has a N-S direction west of VES 3 (S2) and has a length of $450 \mathrm{~m}$ (between VES's 2 and 3), with a unit electrode separation of $12.5 \mathrm{~m}$ which was increased at each traverse by one unit of $12.5 \mathrm{~m}$ to reach a maximum spacing of $150 \mathrm{~m}$ (i.e. $12.5,25,37.5, \ldots . .150 \mathrm{~m}$ ). The third profile has a W-E direction west of VES 8 (S3). It has a length of $450 \mathrm{~m}$, with a unit electrode separation of $15 \mathrm{~m}$ which was increased at each traverse by one unit to reach a maximum spacing of $150 \mathrm{~m}$ (i.e. $15,30,45, \ldots \ldots, 150$ $\mathrm{m})$. The first and second profiles were carried out with the purpose of detecting the horizontal and vertical facies changes in the subsurface and their effect on the groundwater potential. The third one was conducted to test the phenomenon of general decrease in resistivity of the water-bearing layers (as measured by the VES's) eastward. The three selected sites were also useful to study the upper clay which prevents surface water from infiltrating downwards.

The resistivity meters, Terrameter SAS 300 and Terrameter SAS 1000 , were used during field for measuring the resistance "R" with high accuracy.

\section{Interpretation of the geoelectrical data}

Figure (2) shows some of the field curves representing the area of study. The resistivity values of the first and second cycles of the resistivity curves are characterized by HKQ, KQHK, AKQQ and, KHKQ types (Bhattacharya, P. K. and Patra, H. P. 1968). These cycles represent the surface and near surface variations. They reflect the heterogeneity that 
characterizes the topmost layers. Almost all the VES curves end with low resistivity values, either of the K-type, Q- type or both.

A detailed quantitative interpretation for the VES curves was carried out using the computer programs (Resist, 1988 and RESIX- PLUS, V.2.39, 1999) for non-automatic iteration method in which the field data are compared with data calculated from an assumed layer model. The initial model was constructed as constrained by the lithological succession in the calibration wells and the available hydrogeological data. The resitivities and the corresponding thicknesses of each layer at the Vertical Electrical Soundings are listed in table 1.

To calculate the apparent resistivity values for the two-dimensional imaging profiles, a forward modeling program was used and a non-linear least-square optimization technique was used for the inversion routine (De Groot-Hedlin and Constable, 1990 and Loke and Barker, 1996a)

The computer program RES2DINV, Ver 3.4 written by Loke (1998) has been used for the interpretation of the obtained 2-D resistivity data. It is a Windows-based computer program that automatically determines a twodimensional (2-D) subsurface resistivity model for data obtained from electrical imaging surveys (Griffiths and Barker, 1993).

\section{RESULTS AND DISCUSSION}

The results of the quantitative interpretation of the geoelectrical measurements are represented mainly in the form of geoelectrical cross sections and maps. Discussion of these cross sections and maps reveal the characteristics of the three main geoelectrical units (A, B and C) reached through the basic interpretation process.

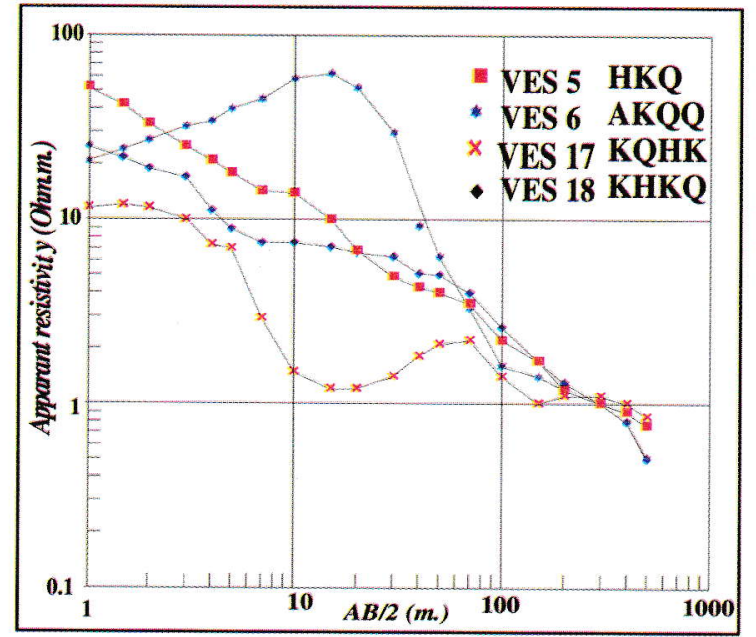

Fig. (2). Examples of the field curves in the study area. 
Table (1). Resistivities and corresponding thicknesses at Vertical Electrical Sounding stations.

\begin{tabular}{|c|c|c|c|c|c|c|c|c|c|}
\hline \multirow[b]{3}{*}{$\begin{array}{l}\text { VES } \\
\text { No. }\end{array}$} & \multirow{2}{*}{\multicolumn{2}{|c|}{ Unit (A) }} & \multicolumn{6}{|c|}{ Unit (B) } & \multirow{3}{*}{$\begin{array}{l}\text { Unit (C) } \\
\text { Resistivity } \\
\text { (Ohm.m.) }\end{array}$} \\
\hline & & & \multicolumn{2}{|c|}{ layer (B1) } & \multicolumn{2}{|c|}{ layer (B2) } & \multicolumn{2}{|c|}{ layer (B3) } & \\
\hline & $\begin{array}{c}\text { Avg. transverse } \\
\text { resistivity (Tpa) } \\
\text { in Ohm.m. }\end{array}$ & $\begin{array}{c}\text { Thickness } \\
\text { (m.) }\end{array}$ & $\begin{array}{c}\text { Resistivity } \\
\text { (T } \rho \text { a in Ohm.m.) }\end{array}$ & $\begin{array}{c}\text { Thickness } \\
(\mathbf{m} .)\end{array}$ & $\begin{array}{l}\text { Resistivity } \\
(\text { Ohm.m. }\end{array}$ & $\begin{array}{c}\text { Thickness } \\
\text { (m.) }\end{array}$ & is $\begin{array}{l}\text { Resistivity } \\
\text { (Ohm.m. })\end{array}$ & $\begin{array}{l}\text { Thickness } \\
\text { (m.) }\end{array}$ & \\
\hline 1 & 142.80 & 2.50 & 26.80 & 22.60 & 0.64 & 7.25 & 16.20 & 24.90 & 0.43 \\
\hline 2 & 84.30 & 5.20 & 16.60 & 20.00 & 0.10 & 7.00 & 12.80 & 27.00 & 0.30 \\
\hline 3 & 15.80 & 4.00 & 23,30 & 16.10 & 0.28 & 6.00 & 7.80 & 32.00 & 0.80 \\
\hline 4 & 12.80 & 3.70 & 8.58 & 17.00 & 0.10 & 7.30 & 6.00 & 30.30 & 0.30 \\
\hline 5 & 26.00 & 3.60 & 17.70 & 14.40 & 0.40 & 7.50 & 6.00 & 30.00 & 0.46 \\
\hline 6 & 127.40 & 5.50 & 8.90 & 15.70 & 0.10 & 4.00 & 6.50 & 3.23 & 0.21 \\
\hline 7 & 188.60 & 3.70 & 24.60 & 15.30 & 0.10 & 4.80 & 7.35 & 31.00 & 0.40 \\
\hline 8 & 20.40 & 5.90 & 7.50 & 13.20 & 0.14 & 7.60 & 7.00 & 32.80 & 0.40 \\
\hline 9 & 70.70 & 5.30 & 13.30 & 20.40 & 0.10 & 8.40 & 12.10 & 25.00 & 0.30 \\
\hline 10 & 63.40 & 5.60 & 29.50 & 20.40 & 1.00 & 10.30 & 15.60 & 23.00 & 0.80 \\
\hline 11 & 89.40 & 4.80 & 26.50 & 25.10 & 0.30 & 7.10 & 11.10 & 24.20 & 0.30 \\
\hline 12 & 33.80 & 3.20 & 7.30 & 19.10 & 2.50 & 8.00 & 10.80 & 24.90 & 1.60 \\
\hline 13 & 33.60 & 4.40 & 4.90 & 25.20 & 1.50 & 7.40 & 6.00 & 27.00 & 0.82 \\
\hline 14 & 68.00 & 2.90 & 8.00 & 13.20 & 0.10 & 6.20 & 4.70 & 31.50 & 0.20 \\
\hline 15 & 26.90 & 2.84 & 5.50 & 18.00 & 0.30 & 10,00 & 6.00 & 23.60 & 0.63 \\
\hline 16 & 9.00 & 4.00 & 5.10 & 20.00 & 0.20 & 9.00 & 6.10 & 24.00 & 0.30 \\
\hline 17 & 7.80 & 4.10 & 7.70 & 12.70 & 0.10 & 9.10 & 6.00 & 31.20 & 0.62 \\
\hline 18 & 15.70 & 2.80 & 14.50 & 17.30 & 0.14 & 7.50 & 8.20 & 25.90 & 0.12 \\
\hline 19 & 52.00 & 2.40 & 22.00 & 22.20 & 0.30 & 7.50 & 10.30 & 23.50 & 0.50 \\
\hline 20 & 17.50 & 3.30 & 13.20 & 26.80 & 0.60 & 7.00 & 16.10 & 22.00 & 0.30 \\
\hline 21 & 31.60 & 2.88 & 30.80 & 18.00 & 0.20 & 7.70 & 7.17 & 25.20 & 0.20 \\
\hline
\end{tabular}

\section{a- Cross sections based on vertical Electrical Soundings.}

The study of the Geoelectrical cross sections A-A' and B-B', shown in figures 3 and 4 , indicates the following:

1- The first geoelectrical unit " $A$ " represents the surface layer. It consists of a group of dry thin sub-layers varying in number from one place to another. It consists generally of sand and sandstone with a thickness of $2.5 \mathrm{~m}$. (VES 3) $5.9 \mathrm{~m}$. (VES 7) and resistivity more than 70 Ohm-m. Intercalations of silt, clayey sand and sandy clay within this unit decrease its resistivity in some places to the range of $8-55 \mathrm{Ohm}-\mathrm{m}$. The base of unit (A) is dominated by clay lenses at some sounding stations that vary from 1 to $4.3 \mathrm{~m}$ in thickness and 1 to $4 \mathrm{Ohm}-\mathrm{m}$ in resistivity.

2- The second unit downward, unit " $\mathrm{B}$ " represents the water bearing formation in the study area. It is regarded to consist of three layers, an upper layer "B1" and a lower one "B3" separated by a thin clay layer B2. $\mathrm{B} 1$, in turn consists of some thin layers governed by lateral facies changes. It has the same lithological composition as the surface layer. However, the average transverse resistivity of this layer ranges from 2 $\mathrm{Ohm}-\mathrm{m}$ to $31 \mathrm{Ohm}-\mathrm{m}$, due to its water content. Clay intercalations in the form of clay lenses are present within this layer. Such lenses are 2-6 m thick with resistivity less than $5 \mathrm{Ohm}-\mathrm{m}$. The overall thickness of the layer ranges from $12.7 \mathrm{~m}$ at VES 13 to $26.8 \mathrm{~m}$ at VES 5. This layer is separated from the underlying layer "B3" by a clay layer (B2) $4-8 \mathrm{~m}$ thick as shown in figures $4,5,6$, and 7 with a resistivity not exceeding 
$0.5 \mathrm{Ohm}-\mathrm{m}$. The lower geoelectrical layer "B3" consists of sandy clay to clayey sand. It is saturated with water having higher salinity than that of "B1". Both the lithologic composition and the higher salinity content are reflected in the value of resistivity calculated for this layer, being 6-16 Ohm-m, which is lower than that of the overlying layer "B1". The thickness of this layer varies from $22 \mathrm{~m}$ at VES 5 to $32.8 \mathrm{~m}$ at VES 7.

3- The last geoelectrical unit downward is unit " $\mathrm{C}$ ", the base of which was not reached with the maximum electrode separation used in this study. The resistivities of this unit do not exceed $0.5 \mathrm{Ohm}-\mathrm{m}$. Such low resistivity values may be attributed to sea water intrusion.

\section{b- Cross sections based on Two-Dimensional Imaging}

Figures 5, 6 and 7 show the 2-D profiles obtained for the three selected sites in the study area, S1, S2 and S3.

The interpretation results at the first site $\mathrm{S} 1$ (Fig. 5) indicates that the near surface layer has a resistivity value ranging from 10 to more than 40 $\mathrm{Ohm}-\mathrm{m}$ which corresponds to sandy clay to sand. The water table lies at a depth of about $4 \mathrm{~m}$ from the surface. Two water-bearing layers were detected but the clay in between is not detected, this may be due to the large electrode separation used.

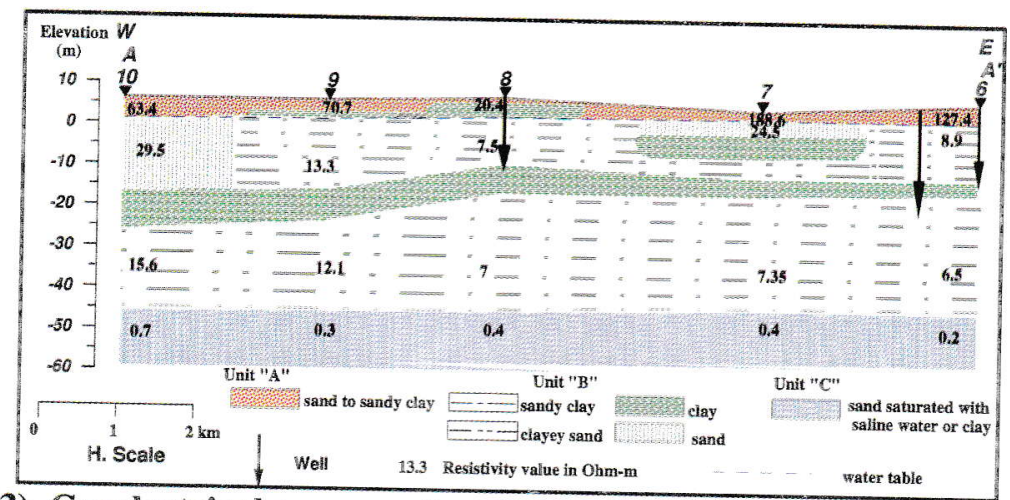

Fig. (3). Geoelectrical cross section $A-A^{\prime}$

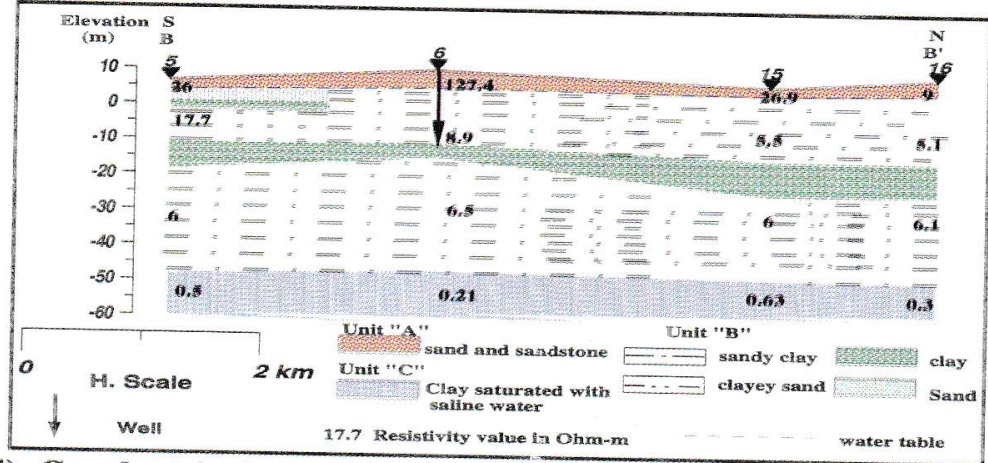

Fig. (4). Geoelectrical cross section $B-B^{\prime}$ 
The first one extends to a depth ranging from about $12 \mathrm{~m}$ at the electrode locations of $120-150 \mathrm{~m}$ and $275 \mathrm{~m}$ to a depth of about $22 \mathrm{~m}$ at the electrode locations of $370-390 \mathrm{~m}$. This zone has resistivity values varying from 12 to more than $37 \mathrm{Ohm}-\mathrm{m}$. These resistivity values correspond to a lithology of sandy clay to sand. Some small clay lenses lie directly below the water table with a resistivity of $2-5 \mathrm{Ohm}-\mathrm{m}$ and were detected at electrode locations of $40 \mathrm{~m}$ and $220 \mathrm{~m}$. A low resistivity layer lies below the shallow water-bearing zone. It has a resistivity range of $2.6-5 \mathrm{Ohm}-\mathrm{m}$. Its thickness generally ranges from 5 to $10 \mathrm{~m}$. These clay lenses are interrupted at electrode locations of $150 \mathrm{~m}, 180 \mathrm{~m}, 250 \mathrm{~m}$ and $310 \mathrm{~m}$. This clay has circular and oval forms and extends to large depths $(45 \mathrm{~m}$.) Beneath the low resistivity zone another water bearing layer was detected. It has a resistivity value ranging from 7 to more than $37 \mathrm{Ohm}-\mathrm{m}$, which corresponds to sandy clay beneath electrode locations of $100-140 \mathrm{~m}$, to water-bearing sand beneath electrode locations of $280-320 \mathrm{~m}$. This zone has a thickness ranging from 20 to $25 \mathrm{~m}$. This profile ends with a low resistivity value less than 0.5 Ohm-m.

The true resistivity plot of the two-Dimensional (2-D) imaging profile at the second site S2 (Fig. 6) indicates that the near surface layer has a resistivity value ranging between about 20 and more than $90 \mathrm{Ohm}-\mathrm{m}$ which corresponds to clayey sandy to sand. The water table lies at a depth of about $5 \mathrm{~m}$ from the surface. Two water bearing layers were detected with clay in between. The shallower one extends to a depth ranging from about $10 \mathrm{~m}$ beneath the electrode location of $200 \mathrm{~m}$ to about $20 \mathrm{~m}$ at the electrode locations of $62.5-87.5 \mathrm{~m}$. This zone has a resistivity value ranging from 14 to about $60 \mathrm{Ohm}-\mathrm{m}$. These resistivity values correspond to a lithology ranging from sandy clay to sand. A low resistivity zone with irregular form lies below the shallow water- bearing zone. It has a resistivity of 5-9 Ohm$\mathrm{m}$. Its thickness generally ranges from $5 \mathrm{~m}$ below electrode location of $200 \mathrm{~m}$ to about $20 \mathrm{~m}$ beneath the electrode location of $150 \mathrm{~m}$. This zone is interrupted at some locations, as at the site below electrode location $405 \mathrm{~m}$. Beneath the low resistivity zone another water-bearing layer was detected at some electrode locations (210-285m).

It has a resistivity value ranging from 14 to more than $36 \mathrm{Ohm}-\mathrm{m}$ which corresponds to sandy clay to water-bearing sand. This zone has a thickness of 20-25 m. Again the resistivity value decreases gradually until it reaches less than $0.5 \mathrm{Ohm}-\mathrm{m}$ at the depth of about $58 \mathrm{~m}$.

The interpretation results of the true resistivity value of the 2-D imaging profile at the third site, S3 (Fig.7) reveal that the succession has low resistivity values as compared with the other two imaging profiles in the area of study. This reflects the facies changes along the study area from one place to another. The near surface layer has a resistivity value ranging between about 5.8 and about $15 \mathrm{Ohm}-\mathrm{m}$ which corresponds to clay to sandy clay facies. The water table lies at a depth of about $4 \mathrm{~m}$ from the surface. Two 
water-bearing layers along this profile are present and consist of sandy clay. At the most, one water-bearing layer is detected followed by clay except at minor locations where two water layers were detected with clay in between. The first water bearing layer has a resistivity value that ranges from about 6 to $15 \mathrm{Ohm}-\mathrm{m}$. Its thickness ranges from $12 \mathrm{~m}$ (beneath electrode locations $150-180 \mathrm{~m}$ ) to $25 \mathrm{~m}$ (beneath electrode locations of $350-375 \mathrm{~m}$ ). The clay layer has a resistivity value less than $5 \mathrm{Ohm}$-m. Its thickness ranges from 9 $\mathrm{m}$ (beneath electrode location of $120 \mathrm{~m}$ ) to about $45 \mathrm{~m}$ (beneath electrode location of $165 \mathrm{~m}$ ). The second water-bearing layer is located only below electrode locations of $100-120 \mathrm{~m}$ that extends to a depth of about $47 \mathrm{~m}$ and at electrode location $200 \mathrm{~m}$ that extends to a depth of $40 \mathrm{~m}$. This layer has a resistivity range of 6-8 Ohm-m.

The minimum detected resistivities along these profiles $(<0.5 \mathrm{Ohm}-$ m) are observed at a depth of $50-58 \mathrm{~m}$. This corresponds to either sand saturated with saline water and /or clay.

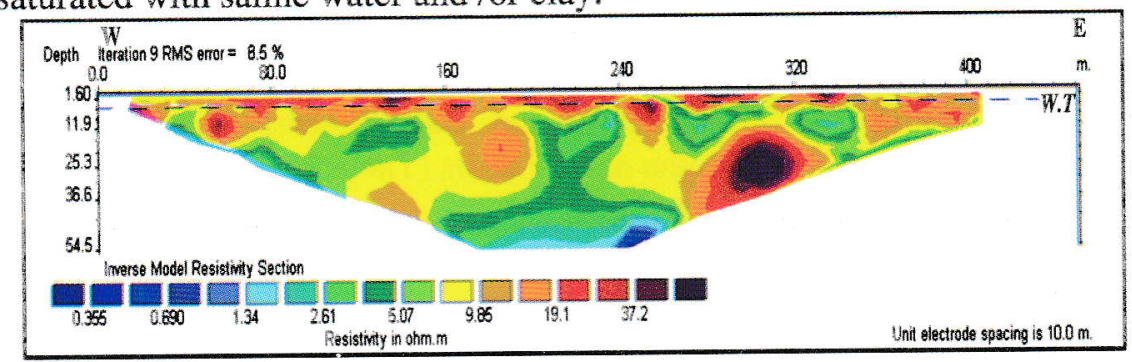

Fig.(5). True resistivity 2-D imaging profile at the first site S1.

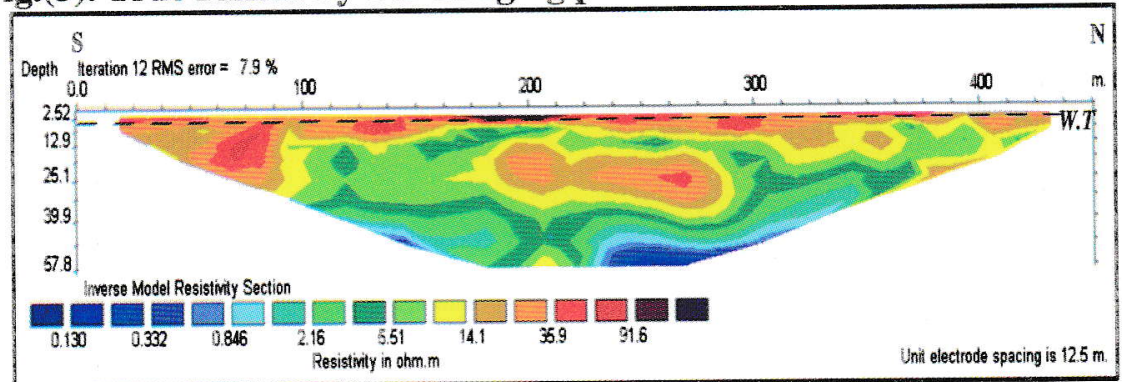

Fig. (6). True resistivity 2-D imaging profile at the second site $S 2$.

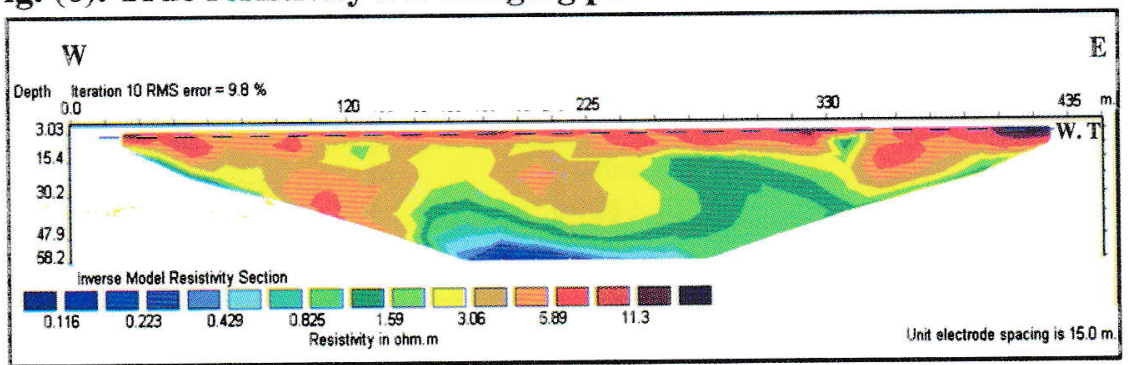

Fig. (7). True resistivity 2-D imaging profile at the third site S3. 


\section{GROUNDWATER POTENTIALS AND LITHOLOGIC FACIES CHANGES}

The results of interpretation of the resistivity sounding curves as well as the hydrogeological data of the 4 drilled wells in the area of study indicate that groundwater is found within Unit "B". The groundwater in the upper part of this unit (geoelectrical layer B3) is present under unconfined condition where that of the lower part (geoelectrical layer B2) is present under semi-confined to confined conditions. The depth to water ranges from $2.5 \mathrm{~m}$ at the northwestern part to $5.9 \mathrm{~m}$ at the middle and southern part (Fig. 8).

The thickness of the upper part (B1) (Fig. 9) increases westward from $12 \mathrm{~m}$ in the east to $26.8 \mathrm{~m}$ in the west. On the other hand, the thickness of the lower part of unit "B" increases towards the southeast from $22 \mathrm{~m}$ to 32.8 m.

The lateral and vertical facies change in the study area was found to have a great impact on the groundwater salinity. This was revealed through the comparison of the resistivity of the water-bearing layer with the corresponding water salinity in the nearby wells (Table 2 ).

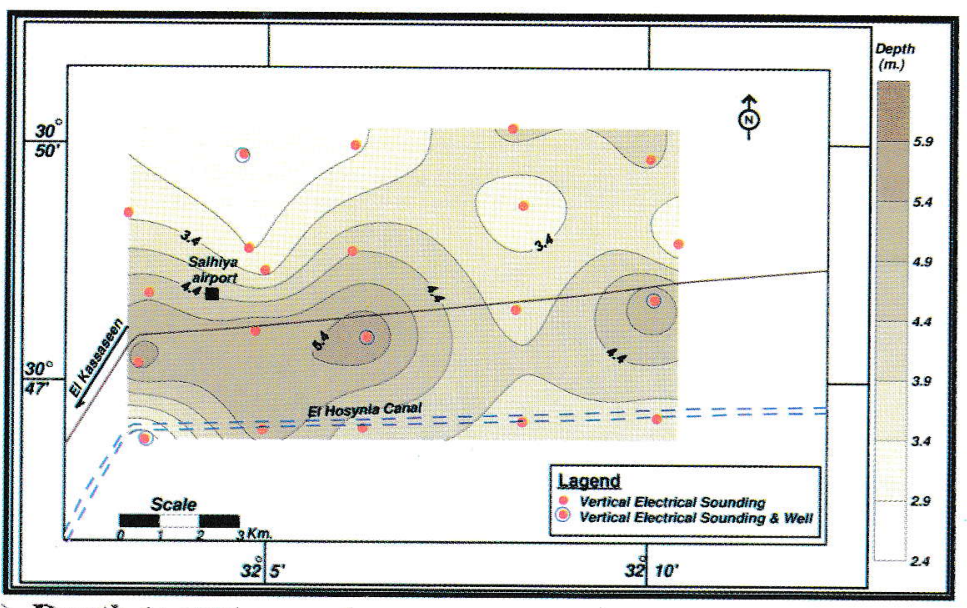

Fig. (8). Depth to water contour map.

Table (2). Water salinity and resistivity values of the geoelectrical layer "B1".

\begin{tabular}{|c|c|c|}
\hline VES and Well & $\begin{array}{c}\text { Salinity } \\
(\mathbf{p p m})\end{array}$ & Resistivity (Ohm-m) \\
\hline $\mathbf{1}$ & 1100 & 26.8 \\
\hline $\mathbf{1 9}$ & 1466 & 22 \\
\hline $\mathbf{6}$ & 2540 & 8.9 \\
\hline $\mathbf{8}$ & 2620 & 7.5 \\
\hline
\end{tabular}


For geoelectrical layer "B1", it was found that the lower the resistivity value, the higher the salinity due to the increase in clay content which in turn increase the salinity and vice versa.

Therefore, the western part of the study area which has the higher resistivity values (Fig. 9) is expected to have less salinity. On the other hand, the northeastern and eastern parts having less resistivity values are expected to have higher salinity. For geoelectrical layer "B1", it was found that the lower the resistivity value, the higher the salinity due to the increase in clay content which in turn increases the salinity and vice versa. On the other hand, the northeastern and eastern parts having less resistivity values are expected to have higher salinity.

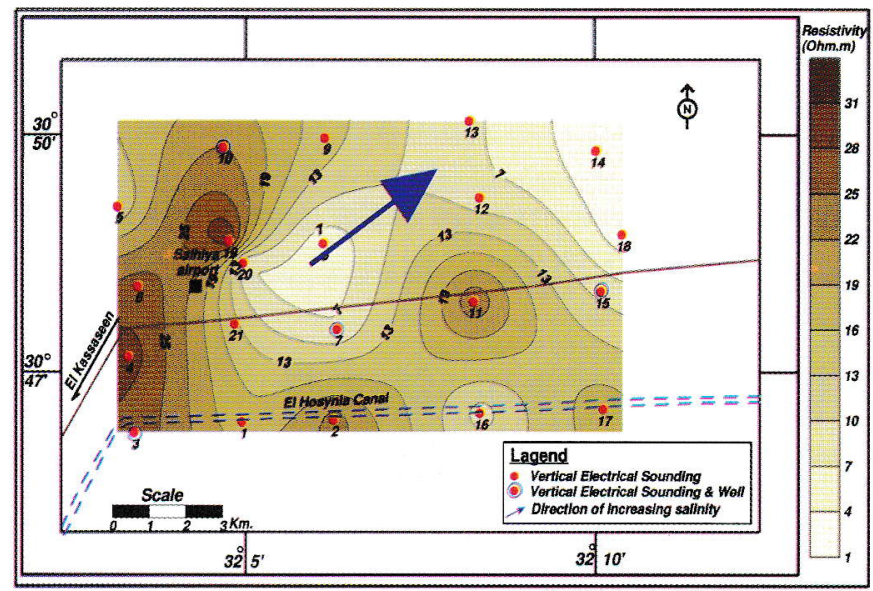

Fig. (9). Iso resistivity contour map of the geoelectrical layer "B1".

Geoelectrical layer "B2" has a lower resistivity value as compared with layer "B1" (Fig. 10). Therefore, it is expected that layer "B2" has more salinity than layer "B1". This was confirmed by measuring the water salinity of two adjacent wells at VES 6 (cross section B-B', Fig. 4). The first well, tapping layer "B1", has a salinity of $2540 \mathrm{ppm}$. Where the resistivity is 26.5 Ohm-m, the second well tapping layers "B1 and B2" has a salinity of 2740 ppm., where the resistivity of layer "B2" is $11.1 \mathrm{Ohm}-\mathrm{m}$. Therefore, the sites of higher resistivity values and greater thickness (western part) have the priority for drilling of wells.

\section{Priority of water well drilling}

It could be concluded that the western and southwestern parts of the area are considered as the most promising area for drilling of water wells (VES stations 10,11, 19 in the west and VES station 3 in the south). Drilled wells must be extended to the geoelectrical layer "B2" at these sites to avoid the increase in water salinity. The northeastern and eastern parts of the study area must be excluded from any drilling activity. Figure (11) shows 
the priority for drilling wells according to the values of resisitivity and thickness of the layer (B1).

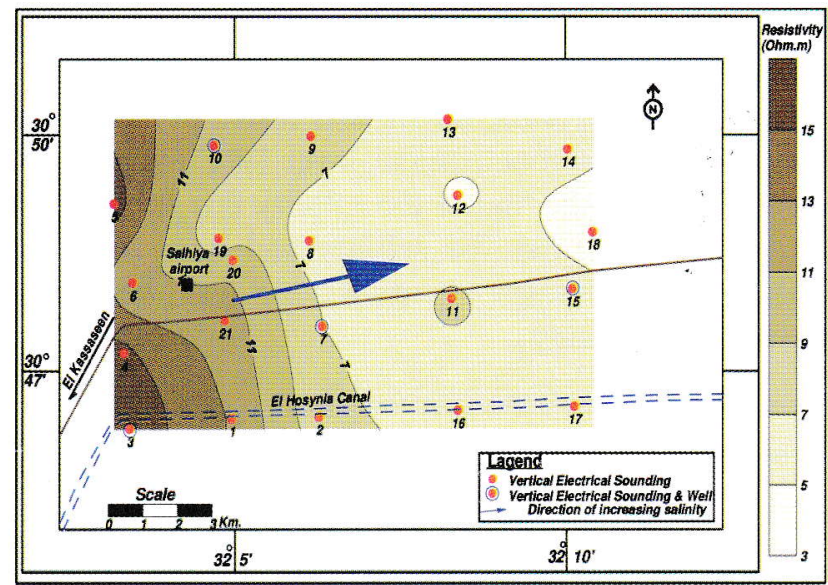

Fig. (10). Iso-resistivity contour map of the geoelectrical layer "B2".

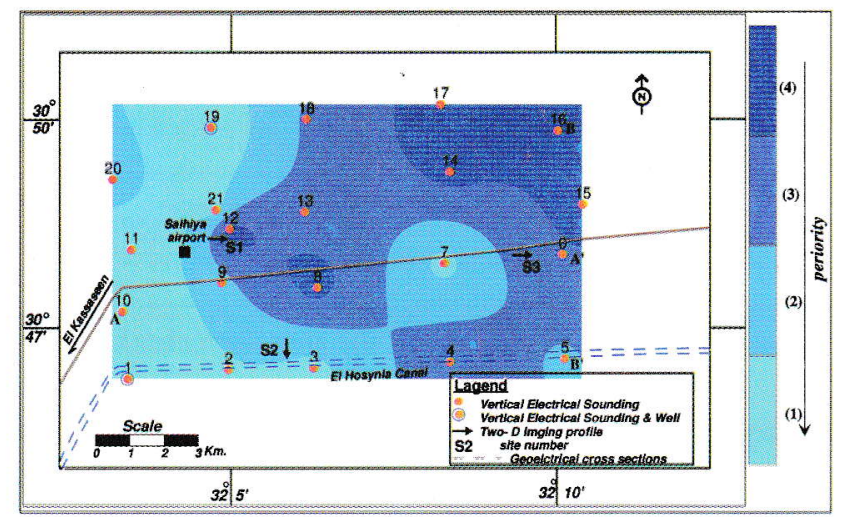

Fig. (11). Priority map for groundwater exploitation along the geoelectrical layer "B1"

\section{SUMMARY AND CONCLUSIONS}

The Quaternary deposits represent the main aquifer in the eastern part of Nile Delta. It is mainly composed of sand and sandstone intercalated with clay. To detect the impact of lithological facies changes on the groundwater potential, the data of twenty one VES stations and three 2-D imaging profiles are interpreted.

The interpretation results of the VES data revealed that the geoelectrical succession is made up of three main geoelectrical units (A, B and C). Unit "A" corresponds to dry sand and sandstone, clayey sand, sandy clay with some clay lenses at its base for some sounding stations. Unit "B" 
represents the water bearing formation in the study area. It consists of two higher resistivity geoelectrical layers (B1 and B3) with a thin clay layer (B2) between them. The high resistivity value of this unit corresponds to sands that change laterally into clayey sand and sandy clay. Generally the lower geoelectrical layer "B3" has lower resistivity values as compared to the upper one ("B1") due to the increase in clay content and salinity of groundwater with depth. The groundwater in the upper part of unit "B" (geoelectrical layer B1) is present in unconfined condition. The depth to water ranges from $2.5 \mathrm{~m}$ at the northeastern part to $5.9 \mathrm{~m}$ at the middle and southeastern part with a general decrease northward. The last detected geoelectrical unit is unit " $\mathrm{C}$ ", with low resistivity value, which may be related to sea water intrusion within this facies or due to dominance of clay composition.

The interpretation results of the 2-D imaging profiles agree with that of sounding interpretations as they confirmed the lithological facies changes in some selected areas. They prove that the clay content increases generally eastward. This in turn indicated that the lower water bearing layer is present under semi-confined to confined condition in the area of study. The presences of clay content near surface which appear from the imaging profiles explain the reason for water logging, especially in the eastern direction.

The lithological facies that changes laterally and vertically have a great impact on the potential and salinity of groundwater in the area of study. This impact has been delineated by comparing the resistivity values of geoelectrical layer "B1" with the corresponding measured salinity of the groundwater for some wells in the area of study penetrating geoelectrical layer "B1" at the same locations. It was found that the lower the resistivity value the higher the salinity due to the increase in clay content and raise the salinity and vice versa. Based on this concept, geoelectrical layer "B3" has higher salinity than that of geoelectrical layer "B1". Therefore, the sites of higher resistivity values and greater thickness (western part) have the priority of drilling wells tapping geoelectrical layer "B1"..Drilled wells must penetrate the geoelectrical layer "B3" only in the western part to avoid relatively higher salinity of groundwater.

\section{From the Two-Dimensional imaging profiles it can be concluded that:}

- The results and interpretations of the soundings (VES) agree with data from the wells.

- The clay content within the layer of sand increases generally eastward as indicated from the decrease in the resistivity values in the third imaging profile.

- The selected profiles indicate clay content near surface that prevents infiltrating water downwards, causing water logging in the area. 


\section{RECOMMENDATIONS}

The groundwater level is expected to rise continuously (water logging) in areas where flood irrigation is used for agriculture, particularly in the low lying parts of the study area and where near surface clay bed is present. For this reason, the following recommendations could be derived from the geoelectrical study applied to the study area:

1- Groundwater should be used to replace the surface water in irrigation to lower the groundwater level in the area to stop water logging, especially in the western part of the area.

2- Modern convenient irrigation systems (drip or sprinkling) must replace the present flood irrigation system to decrease water logging and lower the groundwater salinity.

3- Water wells should have a total depth of less than $25 \mathrm{~m}$ to avoid the more saline water of layer "B3" except in the western part; these wells should extend only to the upper part of layer "B3".

4- Well logging should be conducted in the drilled wells in order to choose the proper well design.

5- Pumping tests should be carried out for the wells to estimate the safe yield of every well.

6- A system of irrigation drains should be constructed to remove the excess water.

\section{REFERENCES}

Bhattacharya, P. K. and H. P. Patra (1968). In "Direct current geoelectric sounding principles and interpretation" Elsevier publishing company Amsterdam, London, New Yowrk, p. 67

Dahab, K. A; E. A. El Abd; M. K. Fattah and M. M. El Osta (2007). "Assessment of groundwater problems of the Quaternary aquifer in the area between El Salhiya El Gidida-Abu Sweir, East Nile Delta Egypt. "GRMENA II, 2007, Cairo Univ., p. 329-353

De Groot-Hedlin, C. and S.Constable (1990). "Occam's inversion to generate smooth, two-dimensional models from magnetotelluric data" Geophysics, 55, p. 1613-1624.

El Fayoumy, I.F. (1968). "Geology of groundwater supplies in the region east of the Nile Delta." Ph.D Thesis, Fac. Sci, Cairo Univ. pp. $1-207$

El Shazly, E.M.; M. A. Abdel Hady; M.M. El Shazly; M.A. El Ghawaby; I.A. El Kassas; A.B. Salman and M.A. Morsi (1970). "Geological groundwater potential studies of El Ismailya master plan study area". Remote sensing Research project, Acad. of Sci. Res. and Techn., Cairo, Egypt, p. 1-24.

Egyptian J. Desert Res., 58, No.2, (2008) 
Griffiths, D.H. and R.D. Barker (1993). Two-dimensional resistivity imaging and modeling in areas of complex geology. Jour. Of Applied Geoph., 29, Elsevier Science Publishers, B.V., Amsterdam, p. 211-226.

Gad, M. I. (1995). "Hydrogeological studies for groundwater reservoirs, East of the Tenth of Ramadan city and vicinities." M.Sc. Thesis, Fac. of Sci., Ain Shams Univ., Cairo, Egypt.

Hefny, K. (1980). "Groundwater in the Nile Valley." Ministry of Irrigation Water Research Center. Groundwater Research Inst.. (in Arabic); 120pp.

Interpex Limited. (1996). "RESIX-PLUS." Resistivity data interpretation software, v.2.39, Golden, Colorado, USA.

Loke, M.H., (1998). "RES2DINV. V. 3.4" rapid 2-D resistivity inversion using the least-square method., $A B E M$ instrument $A B$, Bromma, Sweden.

Loke, M.H. and R.D. Barker (1996a). "Rapid least-squares inversion of apparent resistivity pseudo-sections by a quasi-Newton method". Geophysical Prospecting, 44, p. 131-152.

Moussa, B. M. (1990). Petrology and soil genesis of Surface Quaternary deposits, East of the Nile Delta, Egypt." Ph.D. Thesis, Fac. of Sci., Ain Shams Univ., 391pp.

Said, R. and S. Beheri (1961). Quantitative geomorphology of the area East of Cairo. Bull. Soc. Geographic, Egypt, p. 121-132.

Sallouma, M. K. M. (1983). "Hydrogeological and hydrochemical studies east of the Nile Delta" Ph.D Thesis, Fac. Sci. Ain Shams Univ., $163 p p$.

Shata, A. A. and I.F. El Fayoumy (1970). "Remarks on the regional geological structure of the Nile Delta." Symposium Hydrology of delta, UNESCO, Vol. 1, p. 189-197.

Shata, A. A. (1965). Geological structure of the Nile Delta. J. of Engin. Cairo, (in Arabic), p. 1-3.

Shukri, N. M. and M. K. El Ayouti (1956). "The geology of Gebel Iwiebid, Gafra area, Cairo Suez district. Bull Soc. Geographic, Egypt, p. 67-71.

Van Der Velpen (1988). "RESIST, Version 1.0, a package for the Processing of the resistivity sounding data" M.Sc. Research Project, ITC Dept., The Netherlands.

Received: 21/08/2008

Accepted: 27/01/2009 


\section{استخدام تقتيات المسح الجيوكهريى في تحليد تأثير تفير سحنة الطبقات على

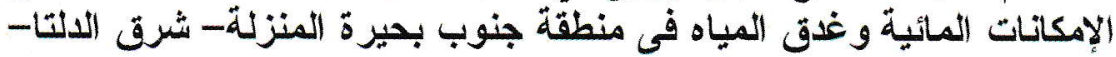

أيمن محمد محمود التمامى، محمد عبد الللاه خالد ومصطفى سعيد مصطفى برسيم

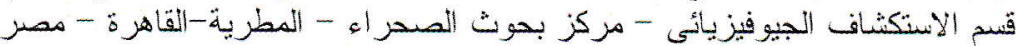

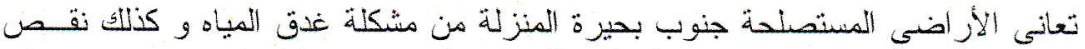

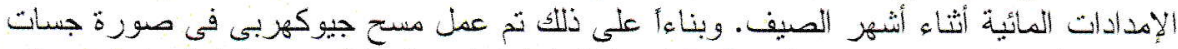

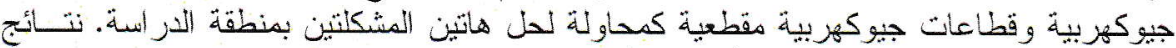

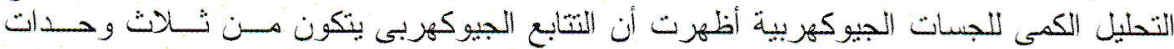

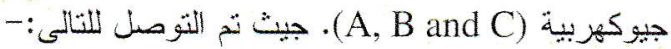

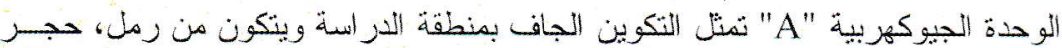

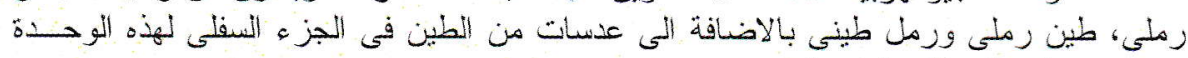
عند بعض الجسات الجيوكهربية.

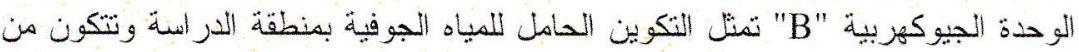

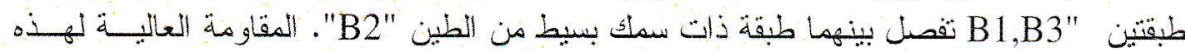

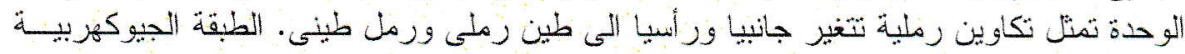

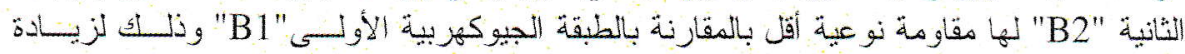

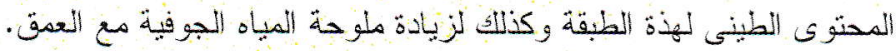

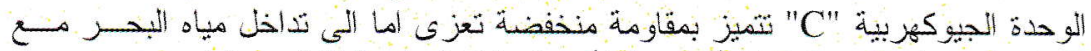
تكاوين الزمال المشبعة بالمياه الجوفية أو نتيجة لأن هذه الطبقة هكونة كلية من الطنين.

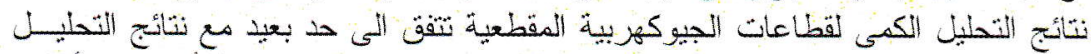

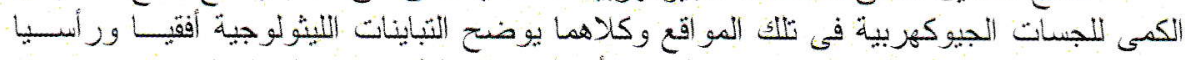

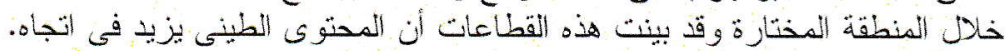

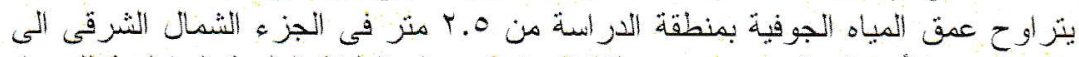

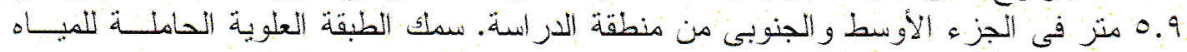

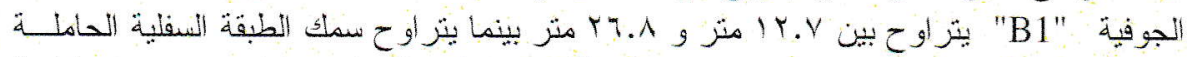

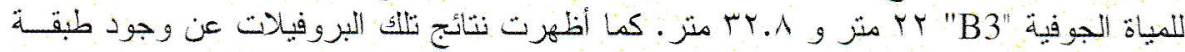

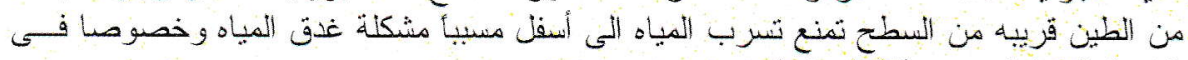
الناحية الثرقية من منطقة الدار السية.

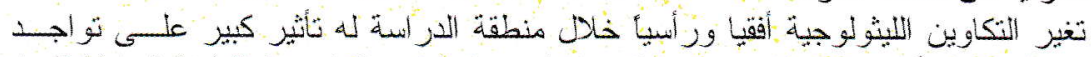

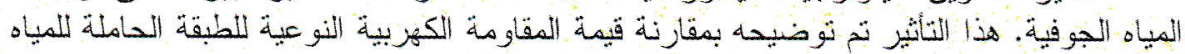

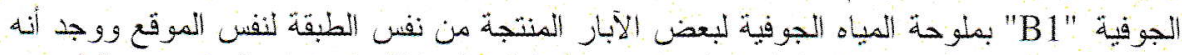

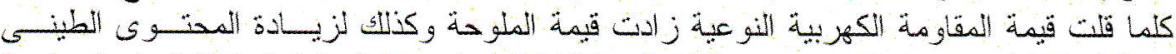

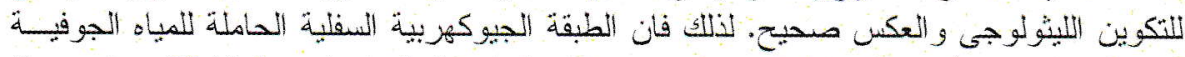

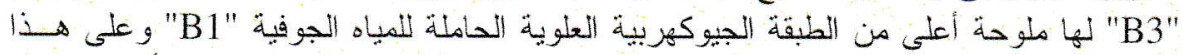

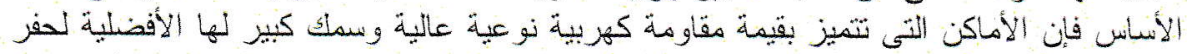

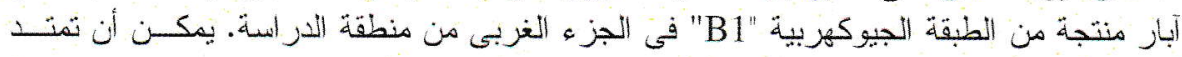

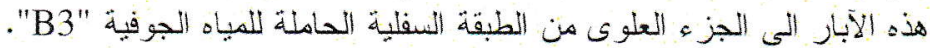

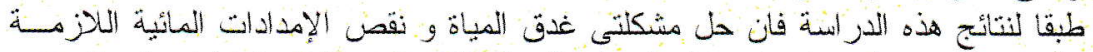

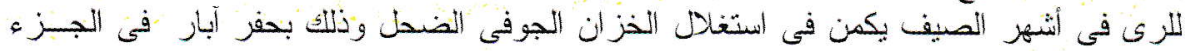


الغربى لمنطقة الدر السة علاوة على انشاء نُبكة جيدة من المصارف واستخدام نظام الرىى بالتنقيط

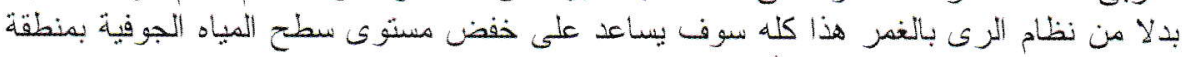
الدر اسة وبالتالى سوف يقلل من تأثير غدق المياه. 